\title{
Efforts to Improve Reading Skills Through the Critical Reading Method for Students of Widya Dharma University on Academic Year 2018/2019
}

\author{
Sri Budiyono ${ }^{1}$, Gunawan Budi Santoso ${ }^{2}$ \\ \{1 sribudyono15@gmail.com, ${ }^{2}$ gunawanbudisantoso1963@gmail.com\} \\ ${ }^{1,2}$ Universitas Widya Dharma, Klaten, Jawa Tengah
}

\begin{abstract}
The ability to read can be interpreted as the will and ability, as well as the readiness of a person to understand the ideas and symbols or sounds of language in a reading text that is tailored to the intent and purpose of the reader to obtain the desired message or information. Reading requires a good understanding, because reading requires a good ability in order to understand the reading text and interpret the reading content well. The ability in the context of learning is an effort to obtain competent fast, fast, and appropriate in dealing with learning problems. Departing from these problems, this study aims: 1) to describe how the reading comprehension condition of the second semester students of Widya Dharma University Klaten in understanding a reading presented bya teacher (read: lecturer); 2) to find out what causes students to have difficulty in understanding a reading given by a teacher (lecturer).
\end{abstract}

Keywords: skills, reading ability, critical reading

\section{Introduction}

The learning process is a curriculum activity in educational institutions as an effort to influence students to achieve the stated educational goals. The purpose of education itself basically leads students towards changes in behavior both intellectually, morally, and socially so that they can live independently as individuals and social beings. But speaking of educational problems, sometimes faced with a chain of problems that is not clear at the base and where to start. How important is education in human life, so that humans are required to demand knowledge through the educational process intended above.

One of the most important elements in the education process is learning and one of the tools for communication is language. Language as a communication tool and a very important tool in daily life, in addition to being a tool for expressing thoughts and feelings towards others and functioning to understand the thoughts and feelings of others.

The above statement is in accordance with the statement of the government through the Ministry of Education and Culture (Depdikbud 1996: 3) which states that the development of Linguistic Intelligence (language ability / intelligence) aims so that humans are able to communicate verbally with their peer environment using Indonesian, both at school, at home, or around the residence.Learning languages (including Indonesian and regional languages) is 
very important for every human being to learn, especially for the students of university Semester II, Widya Dharma University, Klaten, Central Java. However, the knowledge and language skills of reading skills are apparently not easy to transfer. This requires a fairly organized and directed learning process.

\subsection{Identification of Problems}

Based on the above findings, the researcher identified the weaknesses and shortcomings of learning carried out by the researchers so far. The results achieved by students in the third semester before the study were conducted showed grades below the minimum standard (55\%). To know for certain the benefits of applying the method of critical reading to students need to do in-depth research. In this study, students are expected to be able to achieve a minimum pass criteria $(65-85 \%)$, and be able to provide feedback, in the sense of responding to the process of reading the material presented. For this reason, it is hoped that students will have the ability to understand critically the reading material they face. In connection with the statement above, it is necessary to practice systematic and directed which must be preceded by a pattern applied by educators. In the teaching and learning process, one of the approaches to be applied is the ability to read comprehension is by the method of critical reading.

\subsection{Problem Formulation}

Based on the description in the background above, the formulation of the problem in this study is as follows.

a. What is the condition of the reading comprehension ability of the second semester students of Widya Dharma Klaten University in understanding a reading presented by a teacher (read: lecturer)?

b. What makes it difficult for students to understand a reading given by a teacher (lecturer)?

\subsection{Research Objectives}

The purpose of the research achieved in essence is to answer the questions raised in the formulation of the problem. The research objectives are formulated in the following statement.

a. To describe how the reading comprehension condition of the second semester students of WidyaDharma Klaten University in understanding a reading presented by a teacher (read: lecturer);

b. To find out what is causing students to have difficulty in understanding a reading given by a teacher (lecturer).

\subsection{Literature Review}

The reading studies in this article include: reading skills in conceptslearning; critical reading; and the nature of critical reading. For more details, it appears in the following description below.

\subsubsection{Reading Skills in Learning Concepts}

Reading skills is one part of learning in elementary schools, junior high schools, high school, and universities. Reading is a process that is carried out and used by someone to get the message conveyed by the author through print media (written language). From a linguistic perspective, reading is a process of encoding or decoding (a recording and decoding process). An aspect of decoding is the linking of written words with the meaning of oral language (oral language meaning) which includes the conversion of printed matter into meaningful sound, Tarigan [1] summarized Anderson's opinion. 
Actually reading requires that groups of words which are a unity be seen in a glance, and so that the meaning of individual words will be known. If this is not fulfilled, then the written and implied messages will not be captured or understood, and the reading process will not be carried out well, Hodgson [2], compare: Davies and Widdowson [3]; Rubin [4], Mintowati [5]; Muhammed, et all [6]; Rahim [7]; Maedeh, et al [8]; Cheng-Cheng: [9]; Subadiyono: [10].

Reading can also be considered as a process to understand what is implied in what is written, see the thoughts contained in the written words. The level of relationship between the meaning to be expressed by the author and the interpretation or interpretation of the reader also determines the accuracy of reading. The meaning of reading does not lie on the written page but on the reader's mind. Thus the meaning will change, because each reader has a different experience that he uses as a tool to interpret these words [5].

Furthermore, Tarigan [1] suggests that the definition of reading includes: first, reading is a process. This means that information from the text and knowledge possessed by the reader has the most important role in shaping meaning. Second, reading is strategic. Effective readers use various strategic readings that are appropriate to the text and context in order to construct meaning when reading. This strategy varies according to the type of text and the purpose of reading. Third, reading is interactive. The involvement of the reader with the text depends on the context. People who like to read a useful text, will meet several goals that they want to achieve, the text someone reads must be easily understood (readable) so that interaction occurs between the reader and the text. Reading is essentially a complex one that involves many things, not just reciting writing, but also involves visual, thinking, psycholinguistic, and metacognitive activities. As a visual process of reading is the process of translating written symbols (letters) into spoken words. As a thought process, reading includes word recognition activities, literal understanding, interpretation, critical reading and creative understanding. Word recognition can be in the form of word recognition activities, literal understanding, interpretation, critical reading and creative understanding.

\subsubsection{Critical Reading}

Basically, when someone reads critically (critical reading) he is doing reading activities wisely, full of grace, deep, evaluative, and analytical, and not want to find fault with the author, but more than developing knowledge based on what is read. Critical reading is the ability to understand the implied meaning of a reading. For that, we need the ability to think and be critical. In critical reading, the reader processes the reading material critically [1]; [11].

The involvement of thought in terms of understanding reading material is very supportive to facilitate students in particular and readers in general, because we all understand that the process of reading to find out the contents of a reading material, or further understood actually reading critically in the sense of researching carefully is a transfer effort knowledge from books to one's memory or brain. From the above understanding that critical reading is a process of interpreting reading material where the results of the process are then interpreted with student intelligence so that it produces more natural and scientific knowledge, easily developed in building students' ability to the subjects taught. Even more than it will have a very positive impact on the students themselves and the teaching staff because the center of the transfer of knowledge is no longer focused on the teacher, but also is the student, where the teacher lives to provide stimulus to students. In short it can be said that "reading" is "bringing meaning to and getting meaning from printed or written material", picking and understanding the meaning or meaning contained in the written material [11]-[14]. 


\section{Research Method}

\section{1 Types and Research Settings}

This type of research is classroom action research which will be carried out in two cycles. This type of classroom action research was chosen with the aim of being able to offer new ways to improve and enhance the professionalism of teachers in teaching and learning activities in the classroom by looking at various indicators of the success of the process and learning outcomes ". In addition, this class action research is considered easy because it only goes through four stages, namely planning, action, observation and reflection [15].

\section{2 Research Location and Time}

The time and place of research is located at Widya Dharma University, Klaten. The research is planned to be carried out for four months.

\section{3 Research Subjects}

This research was conducted at Widya Dharma University, which is currently teaching material on Teaching and Learning Strategies. As the subject of the study were fifth semester students, Widya Dharma University with a total of 13 students consisting of 3 men and 10 women.

\section{4 Data Collection Techniques}

Data from the results of this study were collected through: 1) Observation sheet which is to record the reading process that took place in the form of successes and weaknesses of the actions given 2) Data about student reading results obtained from practice during the process or after the reading activities took place. On the other hand, the above can be obtained through instruments; 1) Prasiklus Learning Outcomes Data; 2) Data obtained before entering into the research cycle, conducted at the beginning of the meeting using the initial test; 3) Observation Results Data; 4) This data is obtained from direct observations of the learning process carried out by researchers using observation sheets that have been prepared previously in which collaborators always accompany. Observations were made throughout the first cycle and second cycle; 5) Student Learning Outcomes Data.

Student learning outcomes data is student learning outcomes data in the form of reading tests taken during the process and after the learning process takes place. This data can be in the form of written test results according to basic competencies to be achieved in two ways, namely: 1) Post-Cycle Learning Outcomes Data 2) Data obtained after the implementation of cycle I and cycle II, while to find out the increase in reading comprehension of students individually, then carried out re-evaluate the final test.

\subsection{Data Analysis Techniques}

Data collected in the form of quantitative data were analyzed by calculating percentages. This technique is used to obtain a general description of student behavior in the learning process, the effectiveness of actions, and obstacles encountered in carrying out classroom action research and learning outcomes achieved by students at the end of each cycle. The procedure in this quantitative analysis uses the following formula: 
2. 5. 1 Student scores on the initial test, cycle I, and cycle II

Value $=\frac{\text { total value }}{\text { total student }} \mathrm{f} \times 100$

2. 5. 2 Tabulate student scores on the initial test, cycle I, and cycle II

$$
\overline{\mathrm{X}}=\frac{\Sigma \mathrm{X}}{\mathrm{N}}
$$

Information:

$\overline{\mathrm{X}}$ : Average value

$\Sigma \mathrm{X}$ : Total number of student grades

$\mathrm{N}$ : Number of students

2. 5. 3 Calculation of the percentage of student achievement in critical reading

$$
\%=\frac{X 2-X 1}{X 1} \times 100
$$

$\mathrm{X} 1=$ Pre-action

$\mathrm{X} 2=$ Post-action

\section{Results And Discussion}

Classroom action research results obtained from surveys in pre-cycle, cycle I, and cycle II are described in the following explanation.

\section{1 Pre-cycle}

In the pre-cycle moment, a measurement of the understanding of learning achievement is to provide a test to understand questions that have been specifically formulated to students without using the method of critical reading learning. In this case it means that the researcher has not done anything, in the sense of not yet doing the research action. The results of this precycle test were used to determine the initial conditions before the study was conducted. The form of the test used is to understand a question related to working on language skills, working on several questions about spelling, phonology, morphology, semantics, and syntax. The results of this trial were given to the 13 students who were supposed to be there (a number of students sitting in semester VI). However, the seventeen students were only taken by thirteen students because by chance the other four students did not go to class because there were family matters and there were some who were sick, as well as attending campus activities. The thirteen students who were the subjects of the study were: 1) Siti Yulaika; 2) Susan Dwi Wulandari; 3) May Sulastri; 4) Rafika Ilma S; 5) Dhuta Krisna Murti; 6) Galuh Cartur W; 7) Tito Abu Bakar; 8) Fembriana K; 9) Wiji Rahayu; 10) Rhiko Riandanu; 11) Evitasari; 12) Rohmadi; 13) Irene Frista Fifi Natalia. The pre-cycle results can be seen in the following graph 1 illustration. 


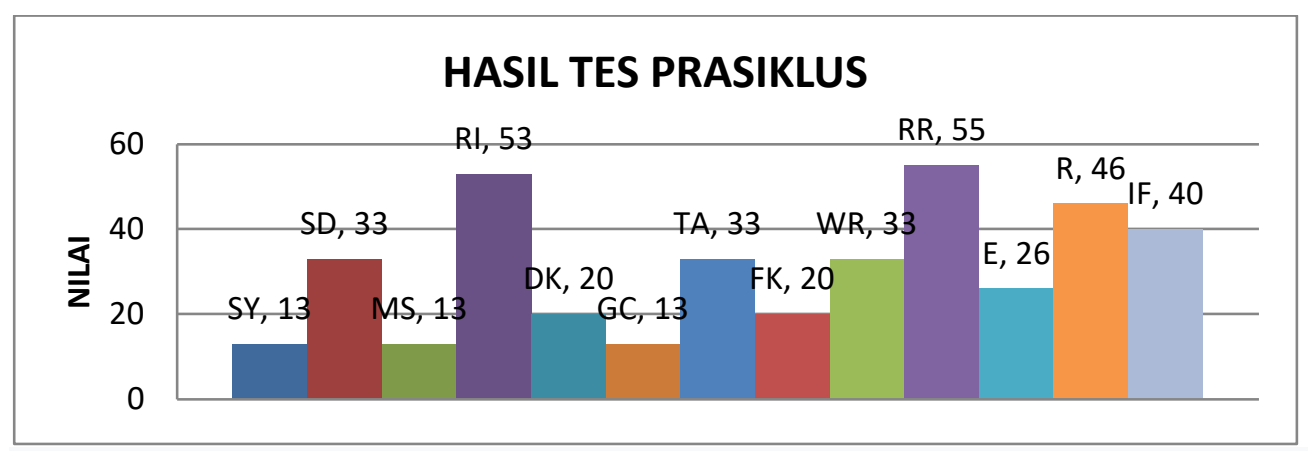

Graph 1: Results of Pre-Cycle Semester VI Students Test on Mastery Indonesian Language Materials prior to the Treatment of Cycle 1 and Cycle 2

\subsection{Siklus 1}

Test results in cycle 1 can be seen in the following graph 2 below.

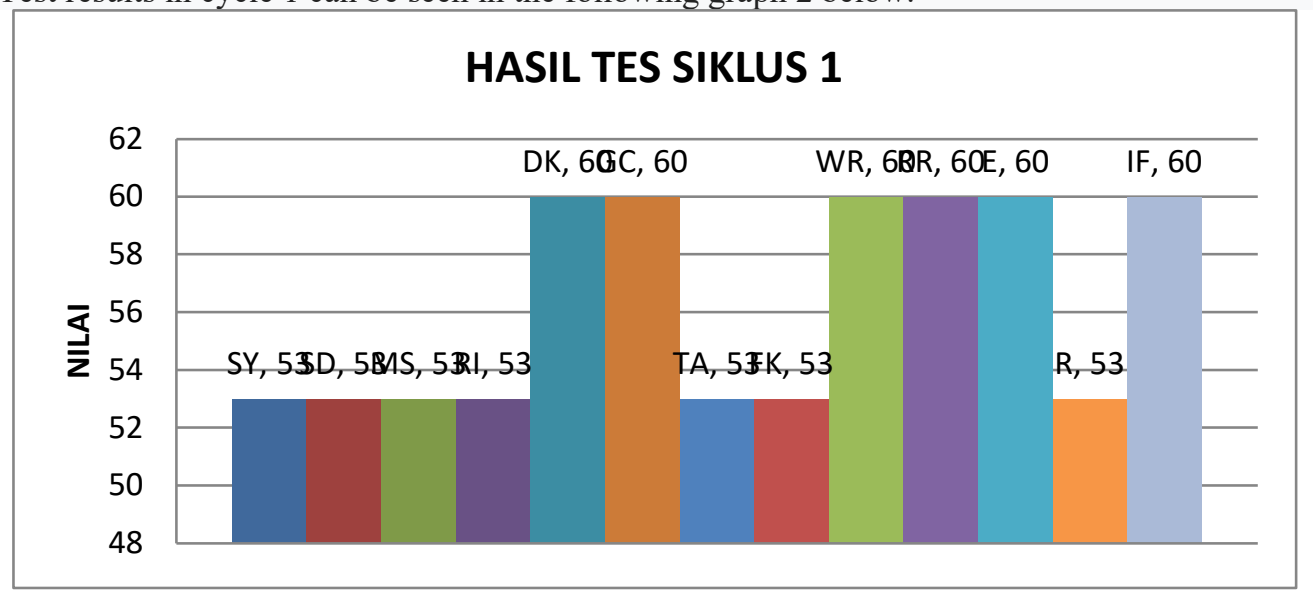

Graph 2: Results of Cycle 1 Test for Semester VI Students on BI Mastery

The results of the test in cycle 1 illustrate that there has been a pretty good increase, although it can be said that it is still not in line with the researchers' expectations. But certainly there has been an increase. Almost all student grades rose, except for one student named Rafika Ilma S. Rafika's scores in the pre-cycle and cycle one remained the same, which was 53. 


\subsection{Siklus 2}

The results of the fifth semester student test in cycle 2 are presented in the following graph 4 below.

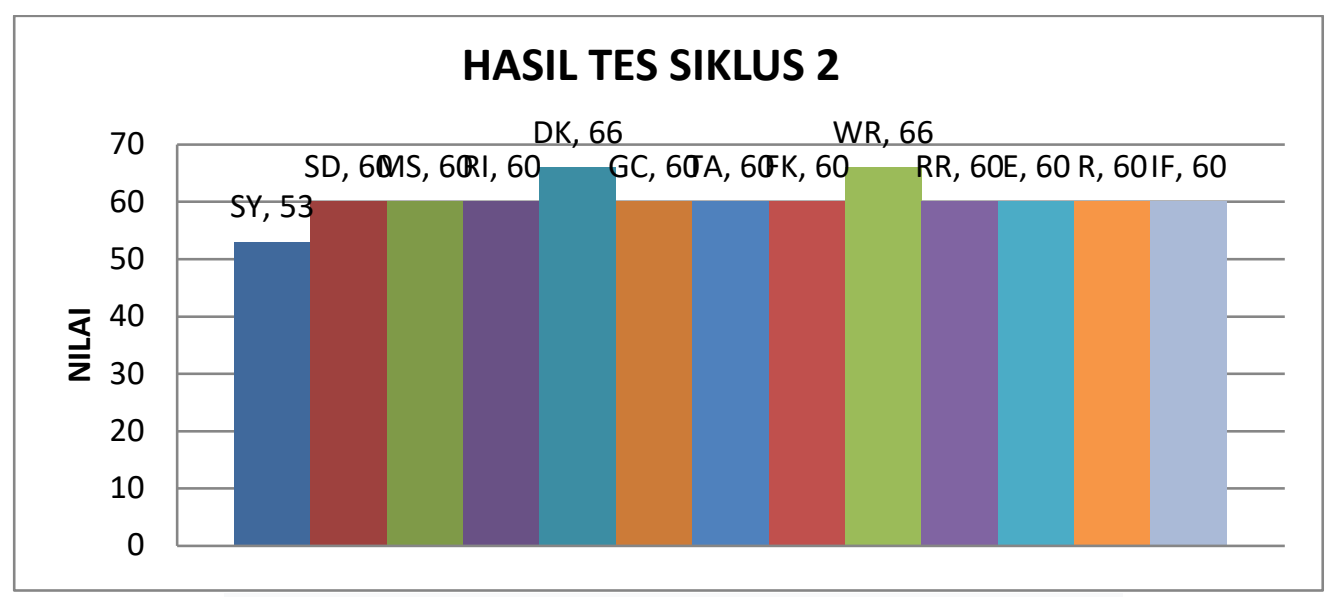

Graph 3: Cycle 2 represent the result tes on Semester VI Student

Furthermore, the results of language acquisition test in pre-cycle, cycle 1 , and cycle 2 are compared. The results of comparative test values in pre-cycle, cycle 1 , and cycle 2 , are presented in Figure 5 below. In Figure 5, it appears that each student has experienced a rise in tilapia, although not significantly significant enough. It can be said that from a very low value, a slight increase although it was not satisfactory, then testing was applied again in the second cycle, apparently there was a significant increase. From the increments it appears that the second cycle, it can be said that all passed even though there are still those who get a score that is not good enough or is said to be of moderate value (below enough). A moderate or below average score was obtained by a student named Siti Yulaika. To see a clear picture can be seen in the following graph 4 below.

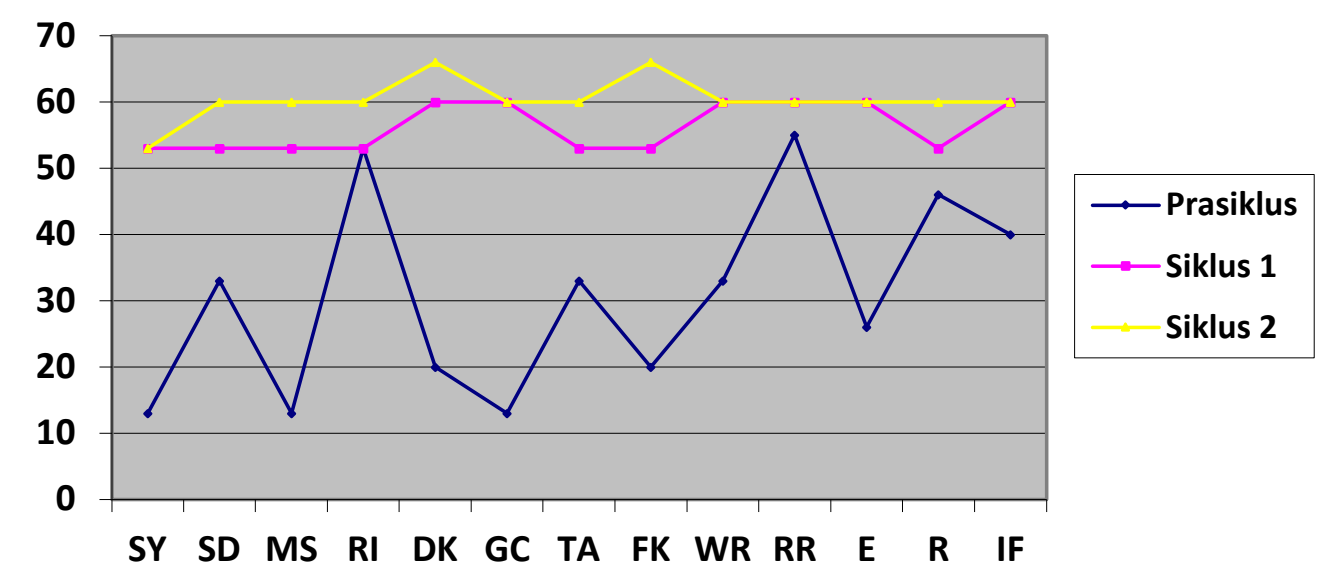

Graph 4: Comparison of increase in value of pre-cycle, cycle 1, and cycle 2. 


\section{Conclusion}

There are two things produced by this research, namely the problem of how the condition of critical reading ability of the second semester students of Widya Dharma University Klaten University and what is the cause of their difficulties in understanding a reading given by a lecturer. For more details are as follows.

\subsection{Condition of critical reading ability of second semester students of Widya University Dharma}

Reading skills of students are still relatively low. Their reading mastery may be said not to be that good. This can be seen and at the same time can be improved after the learning treatment is held by holding a number of test stages, such as the pre-cycle test, cycle 1 and cycle 2 . Before the treatment and testing of the cycle 1 and cycle 2 tests are held, their results may be said to be low or do not meet the standards graduation. However, after the learning process is carried out with plans arranged such as, 1) planning about how steps should be taken to improve their learning achievement, 2) then the learning plan that has been prepared is put into practice in concrete action, 3 ) after that the strengths and weaknesses are examined. (observation), and the last is 4) contemplating to do further actions (reflection) by finding a solution, it turns out efforts to improve reading skills with critical reading methods can be increased .

\subsection{Causes of difficulty for students in reading comprehension.}

Students' reading skills are still lacking due to their mastery of vocabulary and unsupportive environment. The more vocabulary they master will undoubtedly have a very special impact, in the sense of making their understanding increase, which by itself they are able to master the contents in the reading. They will be able to make a synthesis (link the content / core of the problem in the paragraph); make reading conclusions; organizing the main ideas of reading; determine the theme of reading; developing reading frameworks; able to draw conclusions; and at the same time make a summary. For that mastery of vocabulary is very important for students (students) to always be enthusiastic, read a lot, learn to read fast, and immediately try to find solutions about vocabulary that they have not mastered. At least immediately to make or record terms that they have not mastered. In addition, the concept of mastery of concept (metacognitive), in the sense that the more scientific discourse they master, the easier it is for them to master the content of the reading presented in such a reading.

\section{References}

[1] Tarigan, Henry Guntur. 2015. Membaca: Sebagai Suatu Keterampilan Berbahasa. Edisi Revisi. Bamnduing: Angkasa.

[2] Hodgson, F.M.1960. Learning Modern Language. london: Routledge \& Hegan Pau.

[3] Davies, Allen, and H.G. Widdowson. 1974. Reading and Writing, Technique 1 Applied Linguistic. London: Oxford University.

[4] Rubin, D. 1993. A Practical Approach to Teaching Reading. Boston: Allyn and Bacon.

[5] Mintowati, Maria. 2003. Membaca. Jakarta: Depdiknas.

[6] Muhammad, Javed, Lin Iew Eng, and Abdul Roshid Muhammed. 2013. "Developing Reading Comprehension Methods to Facilitate Reading Comprehension among Malaysian Secondary School ESL Students, International Journal of Instruction, Juli, Vol 8, No: 2. 
[8] Maedeh, Ghavamnia, Saeed Ketabi, and Mansoor Tavakoli. 2013. "L2 Reading Strategies Used by Iranian EFL Learners, A Think Aloud Study" Reading Psychology, 34.355-378. Copyright @ Taylor and Francis Group, LLC. ISSN 0270-2771 / 1521-0585 online. DOI: 10.108002702711.2011 .640097

[9] Cheng-Cheng, Tsan. 2015. "Applying the Backward Design Planning Process to Teach English as Foreign Language Reading Comprehension". Modern Journal of Language Teaching Method (MJLTM). Vol. 4, Issue 5, December 2015. ISSN: 2251-6204. USA.

[10] Subadiyono, 2017. "Pengembangan Buku Teks Membaca Kritis". Bahtera: Jurnal Pendidikan Bahasa dan Sastra. Volume 16 Nomor 1 Januari 2017 http://journal.unj.ac.id/unj/index.php/bahtera/ISSN : 0853-2710

[11] Finocchiaro, M., \& Bonomo, M. (1973). The foreign language learner A guide for Teachers. NewYork: Regents.Fulcher.

[12] Tsai, Yea-Ru, Cheryl Ernst, Paul C. Talley. 2010. L1 and L2 Strategy Use in Reading Comprehension of Chinese Efl Readers. Reading Psychology, 31:1-29, 2010. Copyright C Taylor \& Francis Group, LLC.ISSN: 0270-2711 print / 1521-0685 online. DOI: $10.1080 / 02702710802412081$.

[13] Sylvia, Rojas-Drummond, Nancy Mazon, Karen Littleton, and Maricella Velez, 2014. "Developing reading comprehension through collaborative learning ". Journal of Research in Reading. ISSN 0141-0423, Volume 3. Issue 2

[14] Songyut, Akkakoson. 2013. "The Relationship between Strategic Reading Instruction, Students Learning of L2-Based Reading Strategic and L2 Reading Achievement". Journal of Research in Reading. ISSN 0041-0423, Volume 36, Issue 4, pp-422-450. DOI: 10111/jrir.12004. USA

[15] K. Saddhono, I. Mulyaningsih, I. K. Sudarsana, and R. T. Manurung, "Indonesian Language Teachers' Attitudes toward ICT Utilization in Learning for Elementary School in Surakarta," in Journal of Physics: Conference Series, 2019, vol. 1254, no. 1, p. 12062 